\title{
Derelict building installations and infrastructures in Greek Spa Towns: the case of Kamena Vourla and Ypati
}

\author{
E. Beriatos \& M. Papageorgiou \\ Department of Spatial Planning and Regional Development, \\ University of Thessaly, Volos, Greece
}

\begin{abstract}
The evolution of thermal tourism in Greece has caused the construction of numerous imposing building complexes, installations of treatment (spa centers) and hotels (around important thermal springs), which formed the initial cores of future urban development.

During the last two decades, Greek thermal tourism entered a phase of decline. Consequently the above mentioned installations (built up during a long period of flourishing in the 19th and 20th centuries), and especially those found within urban areas, are abandoned and downgraded. Therefore these spa centers deserve the appropriate (architectural) restoration and (urban) renewal in order to reassemble the urban space by filling in the existing 'urban holes', modernize their infrastructure and be able to successfully compete in a more difficult international economic environment.

The Greek spa towns of Kamena Vourla and Ypati are a characteristic example of the above mentioned situation. In Kamena Vourla half of the treatment installations/buildings are completely abandoned while in Ypati the main spa center core is operating in a rather downgraded building construction and several hotels are also empty and nearly ruined.

This paper aims to investigate the possible ways for the restoration, reuse and urban integration of the abandoned installations in spa towns for the benefit of sustainable thermal tourism in Greek regions in the short and long term.
\end{abstract}

Keywords: derelict building-installations, spa town, restoration, urban renewalredevelopment. 


\section{Introduction}

Since ancient times, hot springs, due to their therapeutic characteristics, were a place of attraction for people as well as a place of concentration of various building constructions. For example, in ancient Greece, the Asclepeia were built around or very close to hot springs. The Asclepeia were buildings of God worship and treatment [1]. During Roman times, as proof of the importance given by the Romans to water as a means for achieving good health and vitality, we observe that magnificent bathing facilities were constructed next to hot springs. The most famous are those of the emperors Pompei, Augustus, Agrippa, Titus, Nero, Caracalla, etc [2].

With time and the emergence of the phenomenon of tourism - especially thermal tourism that appeared during the $17^{\text {th }}$ century - the area around hot springs became even more developed. Many hot springs became organized facilities and we see organized bathing centers (spas and hotels). Some of those, the most important, attracted a lot of people and we observe the development of housing facilities for the residence of the permanent population and thus these centers were transformed into spa towns.

\section{Greek spa towns: from prosperity to decline}

Greece is a country rich in hot and cold mineral water springs. According to a survey made by the Institute of Geological and Mineral Research of Greece (in 1984), there are 822 mineral springs evenly distributed in the whole country [3]. From these, the greatest number is found close to the seashores, a small percentage is in flatlands and an even smaller one is in the mountain regions [4].

Having such a natural wealth of thermal water resources, even with some delay in comparison with the rest of Europe, Greece started, almost immediately after gaining independence from Turkish rule, to develop its hot springs, opening the first spa centers in the middle of the 19th century. Since then, thermal tourism was continuously on the rise and in the 1930s - apart from the increase of the number of spa centers - we notice the development of the first Greek bathing-spa towns - the most important of them are Aidipsos, Kamena Vourla, Ypati, Methana, Loutraki, etc [2, 4].

During the Second World War, the rise of thermal tourism in Greece was halted due to the wide destruction - among others - of the spa facilities but thermal tourism recovered relatively soon and started to rise dynamically at the end of the 1950s. Without doubt, the decades from the 1950s to the 1960s and the 1970s were the most flourishing for Greek thermal tourism and the Greek spa towns [5]. A characteristic of this development is the fact that the Greek spa towns were the favorite destination of many famous politicians, tycoons and artists of that era. Among those we can mention, the king of Libya, the king of Saudi Arabia, Aristotelis Onassis, Maria Callas, Winston Churchill, Omar Sharif, Greta Garbo, and many others [2, 6].

The prosperity of the spa towns of this period did not last for long. Since the mid 1980s (a down trend which continues to this day) Greek thermal tourism has been in a period of protracted decline [5]. The number of spa tourists decreases 
continuously and as a result the spa centers are gradually left without repairs and signs of serious abandonment and deterioration are starting to appear. This abandonment and decline is more evident in the spa towns where the building constructions and the infrastructure comprise a very important part of the town itself. Thus, in contrast to the common spa centers - which are usually isolated and in countryside - in the spa towns this abandonment and decline of the bathing facilities and the infrastructure creates a discontinuity of the urban tissue and destruction of the town's identity and operation/functioning.

Nowadays, the abandonment and decline of the bathing facilities and the infrastructure of the spa towns is not a solitary phenomenon but a concern for all Greek spa towns.

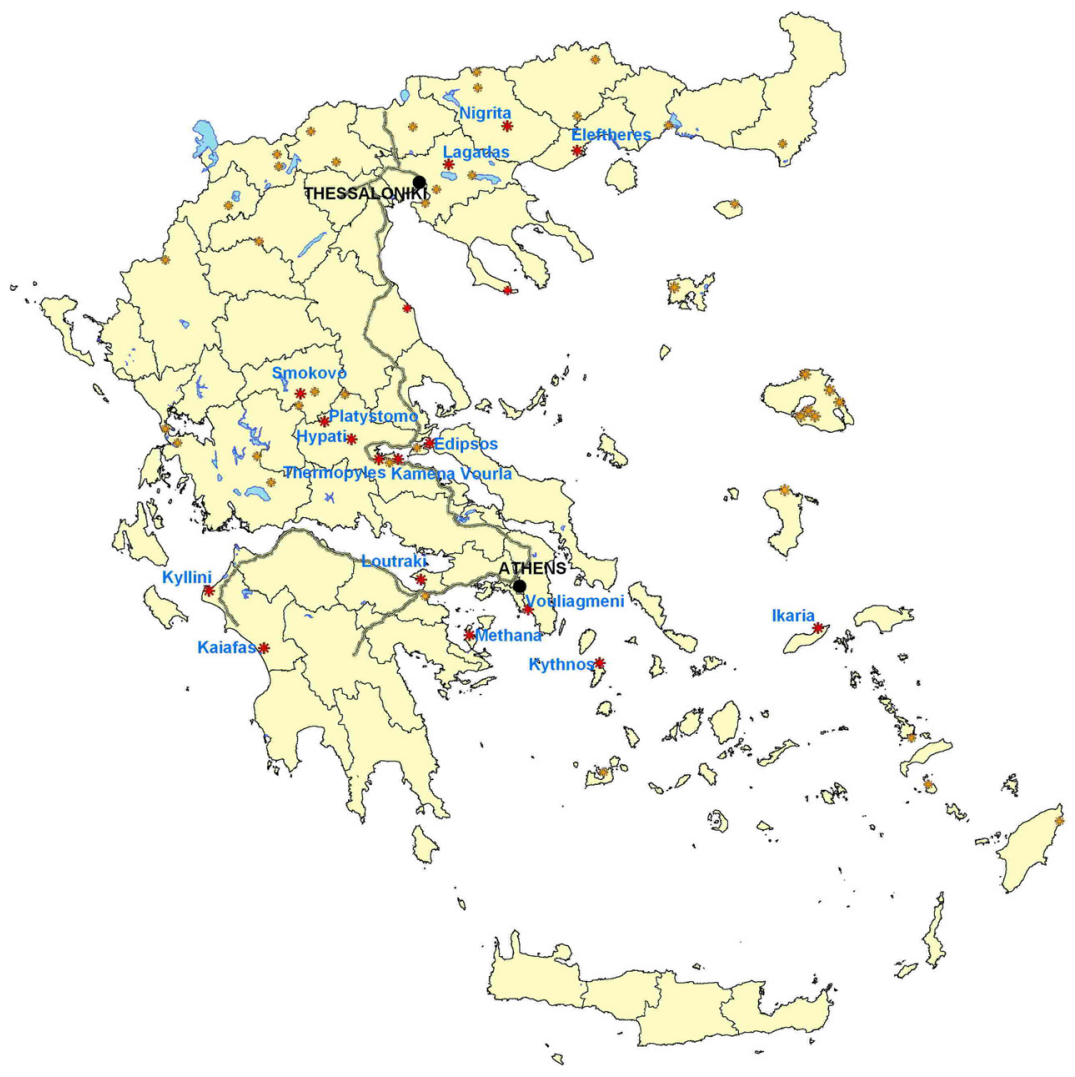

Figure 1: Distribution of the most important spa centers in Greece (source: processed by the authors).

\section{The case of Kamena Vourla and Loutra Ypatis}

\subsection{The spa town of Kamena Vourla}

Kamena Vourla is the second - after Aedipsos - most important spa town in Greece. It is situated in central Greece, at the Prefecture of Fthiotis, along the 
coast - directly on the International Road leading from Athens to Salonika. It is $175 \mathrm{~km}$ from the Greek capital and has a population of 3,500.

The coastal spa town of Kamena Vourla is the most recently built in Greece. The first spa building (Figure 4) was built in 1936 together with the hotel "Kallidromos". Until then there were virtually no buildings in the area, apart from some huts used by sheep and goat herders who came down from the mountains in order to spend the winter months there.

Even though the development of the area as a spa center was halted during the Second World War, Kamena Vourla soon recovered. During the 1950s in the area of the already existing spa center - approximately 60 hectares - (Figure 2), two luxury hotels were built (Figure 3) and in 1974 a second spa was constructed called "Hippocrates", since the town was starting to receive a lot of tourists [7].

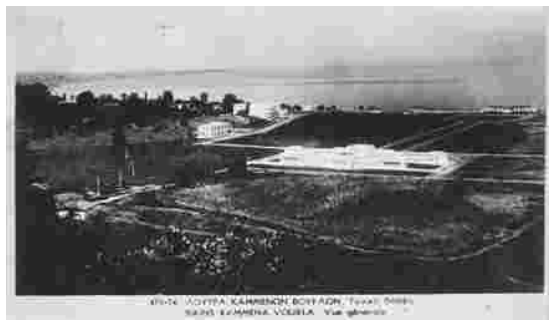

Figure 2: Panoramic view of the spa center area in the 1960s.

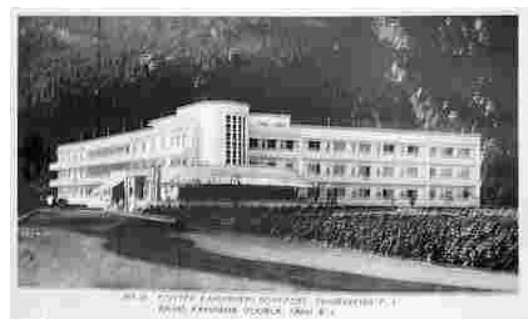

Figure 3: Hotel "radio" in the 1960s.

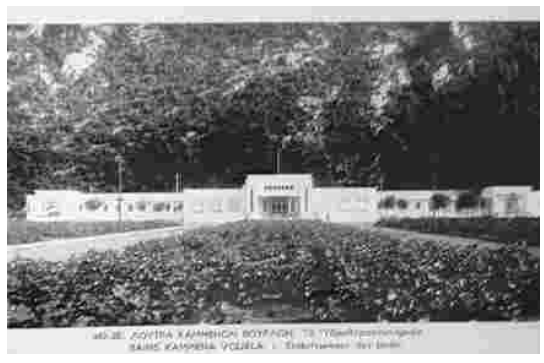

Figure 4: "Asclepios" spa building in the 1960s.

In the meantime, in the broader area - and very close to the spa center -the construction of other hotels, restaurants, shops and houses began. Gradually, the area of Kamena Vourla changed from an isolated spa center in the middle of the countryside, to a small town with permanent residents having at its geometrical center the large area occupied by the spa buildings and its surrounding infrastructure (Figure 5).

Unfortunately, as happened to the rest of the spa towns in Greece, from the mid 1980s, tourism in Kamena Vourla suddenly started to decline - not only in numbers but in quality as well [5]. The number of bathers reduced sharply and 
this resulted in the appearance of the first signs of abandonment, not only inside the spa center but also in the rest of the urban tissue. Especially in the area of the spa center its bathing facilities and infrastructure started to dysfunction and to be surrounded by a downgraded environment.

Some changes started to occur in 2000, when the Greek State gave the rights of use of the spa center to private investors. The spa "Hippocrates" and the hotel "Galini" (Calmness) were largely renovated (the hotel is now operating as a luxury hotel with a wing of spa facilities). Nevertheless, the fact remains that more than half of the spa buildings of Kamena Vourla are still abandoned and surrounded by an even more downgraded environment (Figures 6-8).

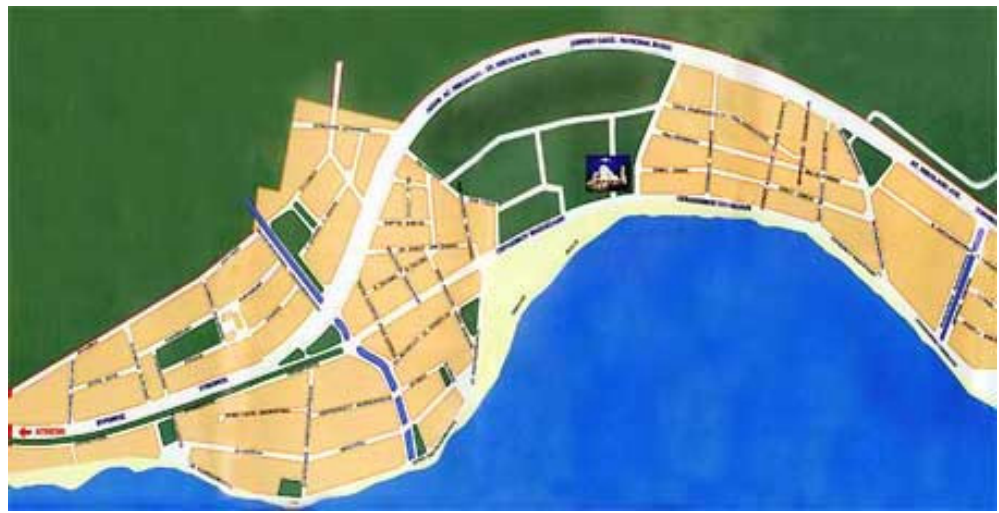

Figure 5: The town plan of Kamena Vourla with the spa center in the urban core.

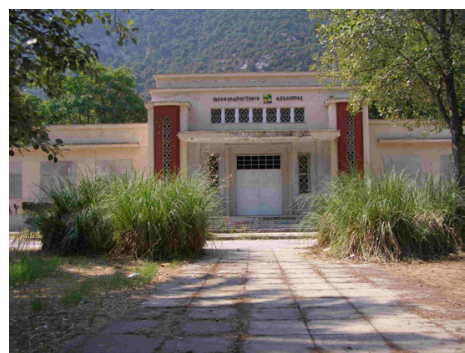

Figure 6:
"Asclepios" building today.

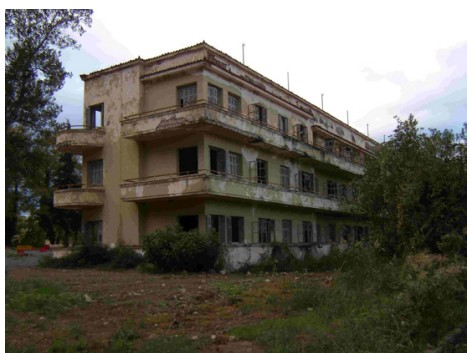

Figure 7: Hotel "Radio" today.

The aforementioned devaluation and abandonment of a large number of spa facilities and the infrastructure of Kamena Vourla resulted in the town: a) losing its spa identity due to the image of decline presented in the spa facilities and their infrastructure, b) having a discontinuity in the residential area since the abandoned facilities and the space surrounding them are in its urban core, c) having $\mathrm{n}$ non-aesthetic aspect since the abandoned facilities are in full view and centrally located and d) losing of a great number of visitors since more than half of the spa buildings are inoperative. 


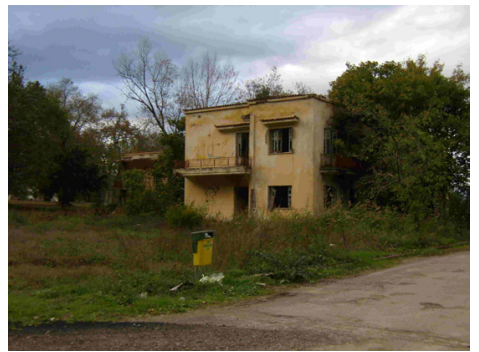

Figure 8: Hotel "Thronion" today.

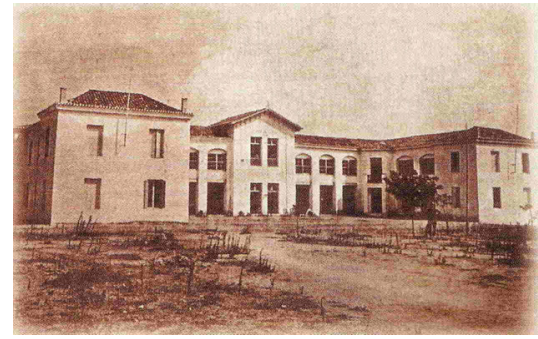

Figure 9: Hotel "Oiti" in the beginning of the 20th century (still operating).

\subsection{The spa town of Ypati ("Loutra Ypatis")}

The town of Loutra Ypatis is the third most important spa town in Greece. It is also in Central Greece in the flatlands of the District of Fthiotis. It is a small spa town with a population of 1,000 residents, built at the foot of Oiti mountain, at a distance of $17 \mathrm{~km}$ from Lamia and $230 \mathrm{~km}$ from Athens. The town also has direct access to the railroad line connecting Athens to Salonika.

Loutra Ypatis is one of the first spa towns that were created in Greece at the end of the 19th century. More precisely, in 1890 the area around the hot springs received an official Town Plan as a token of recognition of the opportunities for development of the area, and two years later (1892) the first spa building was constructed next to the thermal spring (Figure 11). Until then, there were no spa buildings, nor residential development in the area. The building of the spa facilities and of a number of small and large hotels (Figures 9,10) was the cause of tourism development in the area [8-10].

Almost from the very first day of its operation, the spa in Ypati came to be one of the main destinations for spa tourists and thus became one of the main spa destinations in Greece. Very soon, around the spa building, the first restaurants, cafés and shops were constructed and all the people working in these started to reside permanently in the area surrounding the spa building [8-10].

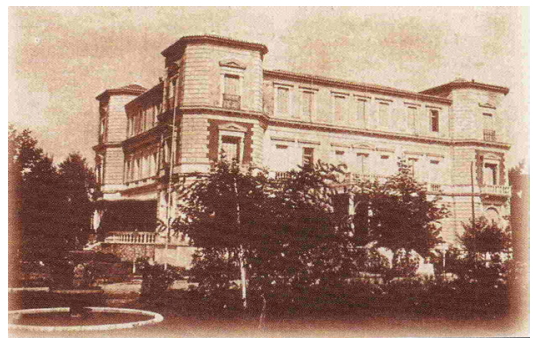

Figure 10: Hotel "Fthiotis" in the beginning of 20th century (destroyed during WWII).

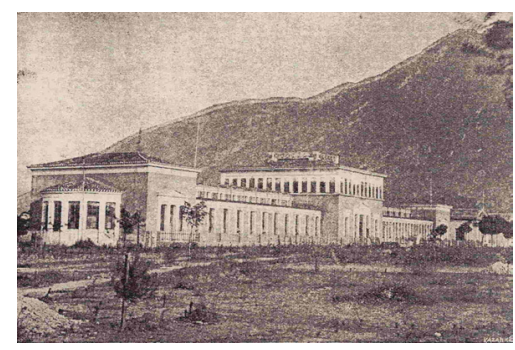

Figure 11: The old spa building (demolished after WWII). 


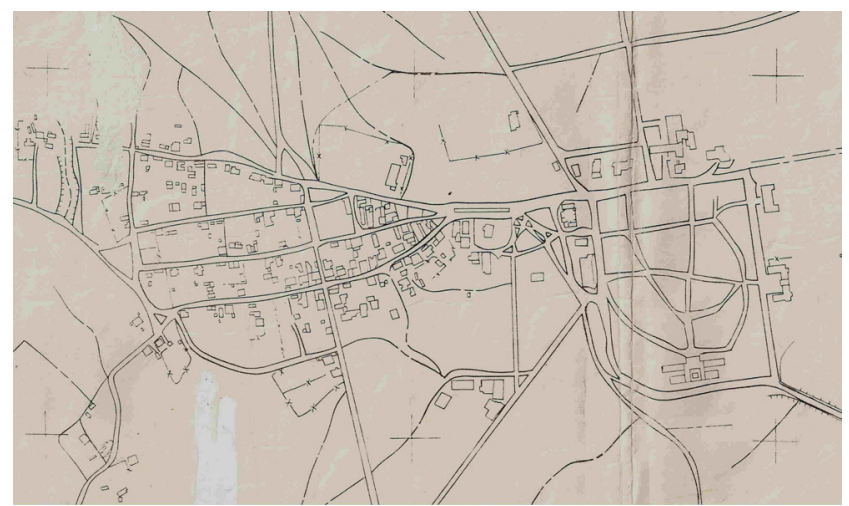

Figure 12: The plan of the spa town of Ypati.

The isolated spa center of Ypati began to be developed into a spa town (i.e. to be developed residentially on a larger scale) after the end of the Second World War. This is also a period when the spa town was entering its most important phase as tourist destination. As was the case for Kamena Vourla, the 1950s, 1960s and 1970s were a period of wealth for the spa town of Loutra Ypatis. In the beginning of the 1960s, the old spa building was demolished and a new one was constructed in order to cover the needs of a great number of people that arrived in the town for thermal treatments. The same happened to the hotel units with the renovation of the older ones and the construction of new ones. The spa town was in a constant state of development and its spa facilities became among the most famous in Greece.

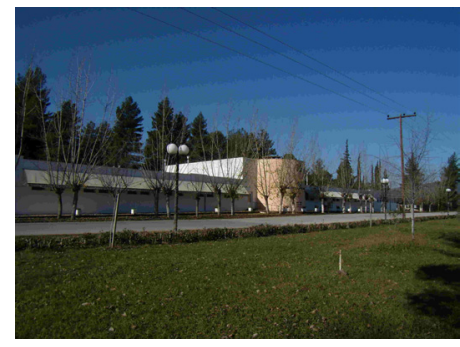

Figure 13: The new spa building (built in the 1960s).

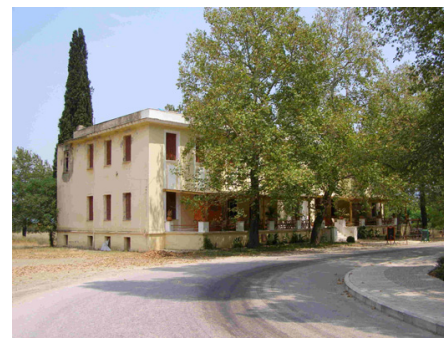

Figure 14: Historic hotel "The Springs" (still operating).

In spite of its previous growth, the fall started in the mid 1980s, which is the period during which we observe the gradual decline of spa tourism in all of Greece, and the spa town of Loutra Ypatis started to lose its splendor, following a negative course that has lasted to this day. In fact, tourism in Loutra Ypatis has decreased dramatically [5] and the spa core of the town presents evident signs of abandonment and neglect. The one - and only - spa building (Figure 13) is operating with evident signs of wear, and most of the hotels that catered to the 
spa tourism of the area are presenting either signs of downgrading (Figure 14) or complete abandonment (Figure 15). At the beginning of the 21 st century, the spa center of Ypati (an area of approximately 90 hectares) presents the image more of a derelict area than a tourist destination. This does not help the aspect of the town nor pays respect to its history as a spa town and even more, creates negativity among investors who might be interested in developing the area.

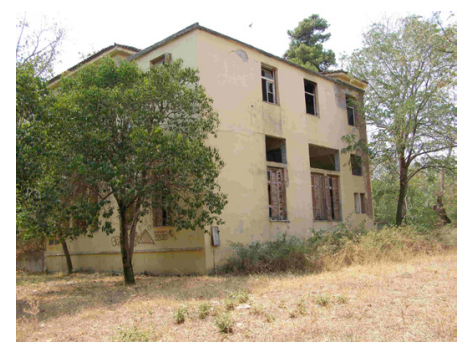

Figure 15: The abandoned hotel "Pavillion".

\section{Restoration and reuse strategies}

As previously mentioned, the two spa towns of Kamena Vourla and Ypati (the second and third in importance among spa towns in Greece) are characterized by strong signs of abandonment and dereliction in the area allocated to their spa center. For this reason and with the aim of overcoming the unfavorable impacts on the urban tissue, a research was conducted in the field, with questionnaires filled in by visitors and bathers. The findings resulting from this investigation demonstrate the need for the realization of some feasible and attainable projects at the building and public space level in order to improve the given image of downgrading of such an important and vital part of these two spa towns. For instance in the case of Ypati only $15 \%$ of thermal tourists are 'very satisfied' with the offered spa facilities while in the case of Kamena Vourla the respective percentage goes up to $40 \%$.

Taking into account the above considerations we are presenting here a series of suggestions and proposals for improving the built environment as for example, those that are described below for each one of the two spa towns (study areas).

\subsection{Spa town of Kamena Vourla}

The restoration and rehabilitation of the buildings of the spa center, firstly of the water spa "Asclepios" (Figures 4 and 6) and secondly of the hotels "Thronion" and "Radio" (Figures 7 and 8) with the aim of improving the offered tourist product and infrastructure.

Remodeling of the existing green spaces surrounding the spa buildings (total area of 60 hectares) with the aim of improving the quality of the environment of the spa center and the town itself. 
Creating continuity with the residential areas of the town by connecting the walks inside the green space of the spa center with the urban tissue, so that people from the town may visit it.

Strengthening the spa identity of the town: Restoration and improvement of the buildings inside the town (mainly historic hotels) with the aim of redefining the identity of the town as a thermal tourist destination. It is also proposed to create landmarks and in certain places introduce town statues, mosaics etc that will have the water and thermal treatment as their main theme.

\subsection{Spa town of Ypati ("Loutra Ypatis")}

The restoration of the old spa building or/and the building of a new one: Restoration of the old spa building according to modern standards and needs of thermal tourism or/and the construction of a new spa building with the aim of attracting a larger number of thermal tourists.

Modernization of the hotel infrastructure surrounding the spa buildings: Restoration and improvement of the already existing hotel infrastructure, especially their facades, so that the image of the spa center and of the whole town might be aesthetically improved.

Restoration of derelict hotels with the aim of offering more - and more qualitative - hotel infrastructure to the visitors of the spa town and furthermore, to lift the image of abandonment.

Establishment of a thermal and historical museum of the town: one of the abandoned hotels in the town should be restored so that a thermal museum can be founded with the aim of strengthening the spa identity of the area and preserving its history.

Regeneration of the existing old park (total area of 90 hectares), upgrading its aesthetic image, with the aim of opening the park to visitors (tourists and local people) and improving the spatial cohesion between the spa center and the rest of the town.

Apart from the above proposed actions and interventions, a major issue that has to be addressed in such cases is the allocation of financial resources and the appropriate financial mechanisms in order to bring about the restoration and upgrading of derelict buildings. An answer to that may be a synergy between the state (central government), the local authorities and the local actors ("tripartite partnership'). Concerning the construction of infrastructures, the cooperation between public and private sectors, which was recently introduced in the Greek institutional framework, should be specifically studied in order to include the case in question. The greatest difficulty will be the maintenance and operation of this infrastructure, which should be financially viable, since this is a necessary condition in the context of a difficult international economic environment caused by the current policy of open markets and globalization.

\section{Conclusions}

It is a fact that in our days the sudden reduction of the number of thermal tourists in Greece has resulted in most of the Greek spa centers showing noticeable signs 
of decline and even - in some cases - abandonment. This unfortunate turn of events for the spa centers is even more evident in the case of the spa towns - i.e. the towns that have been developed 'ex nihilo' around a bathing center. In this case the abandonment of the bathing facilities does not only concern a remote bathing center somewhere in the countryside, but a vital part of a whole town.

In Greece, all of the spa towns - for many decades now - are suffering, if not from complete abandonment at least from a partial one. In the cases of Kamena Vourla and Loutra Ypatis, more than half of the buildings remain derelict and inactive, and the spa centers that once were full of life, are now in a state of neglect thus creating a discontinuity in the urban tissue of these two towns.

For this reason, in the cases of Kamena Vourla and Loutra Ypatis, there is an urgent need for the restoration of the aesthetic and functional character of the spa facilities as well as the reconnecting and restructuring of the urban space. These actions must be taken so that the two spa towns will not only become competitive once more as a tourist destination but also to regain the spatial cohesion and spa identity they deserve in the Greek and Mediterranean world thermal tourism.

In any case, the initiative for the realization of the proposed strategy for spatial development and the achievement of the specific aims depends on political will and is mainly a task of local authorities, which are the direct and valid conveyor of local interests, which should be mobilized with the support of the central government and the financial contribution of local private investors.

\section{References}

[1] Spathi, S., Thermal tourism and the development of health tourism in Greece, Centre of Economic Research and Planning (KEPE), Athens, 2000 (in Greek).

[2] Ministry of Environment, Spatial Planning and Public Works (M.E.S.P.P.W.), Strategic Spatial Planning Study for thermal tourism development in Greece, M.E.S.P.P.W., Athens, 2000 (in Greek).

[3] Ministry of Energy and Natural Resources (M.E.N.R.) - Institute of Geological and Mineral Research (I.G.M.R), Mineral springs of Greece, M.E.N.R. - I.G.M.R., Athens, 1984 (in Greek).

[4] Greek Association of Thermal Spring Municipalities (G.A.T.S.M.)- Greek Thermal Agency (G.T.A.), Thermal Springs and Spa Towns: Greek Thermalism, G.A.T.S.M. - G.T.A., Salonika, 2006 (in Greek).

[5] National Statistical Service of Greece, Statistical Yearbooks (up to 1997).

[6] Zcharopoulos C. and Barbikas M. and Christopoulos J., Greek Spas: Tourist Guide, Kastaniotis, Athens, 2001. (in Greek).

[7] Skouras, C., The spa town of Kamena Vourla, Athens, 1956 (in Greek).

[8] Evagelidis, T., The self-shown medicinal waters of Ypati, Cultura Publications, Athens, $1^{\text {st }}$ edition 1895, republished 2005 (in Greek).

[9] Evagelopoulos, T., The medicinal baths of Ypati, Lamia, 1985 (in Greek).

[10] Gikas, A., Ypati's baths, Municipality of Ypati, 2001 (in Greek). 